\title{
Chory na przewlekłą obturacyjną chorobę płuc (POChP) w opiece lekarza rodzinnego
}

\author{
Patient with chronic obstructive pulmonary disease (COPD) at family doctor
}

Pneumonol. Alergol. Pol. 2014; 82, supl. 2: 11-21

\section{Jak definiuje się POChP?}

Polskie Towarzystwo Chorób Płuc definiuje przewlekłą obturacyjną chorobę płuc (POChP) jako powszechnie występującą przewlekłą chorobę poddającą się profilaktyce i leczeniu. Cechuje się ona utrwalonym ograniczeniem przepływu powietrza przez dolne drogi oddechowe, które zazwyczaj postępuje i jest związane z nadmierną reakcją zapalną w oskrzelach i płucach w odpowiedzi na szkodliwe działanie gazów i pyłów, w Polsce najczęściej dymu tytoniowego. Zaostrzenia i obecność chorób współistniejących wpływają na przebieg POChP u poszczególnych chorych [1].

\section{Epidemiologia}

Najnowsze analizy wskazują, że w krajach Unii Europejskiej POChP występuje u około 15\% powyżej 40 rż., przy czym stopnie II-IV dotyczą 8,8\% ogółu mieszkańców [2].

Nie ma dokładnych danych odnoszących się do liczby chorych w Polsce. Można przypuszczać, że POChP dotyka około $10 \%$ populacji, przy czym około $1 / 5$ chorych ma zaawansowaną postać choroby, z ograniczeniem przepływu powietrza przez oskrzela mierzonym za pomocą wskaźnika $\mathrm{FEV}_{1}$ poniżej (forced expiratory volume in one second) $50 \%$ należnej wartości [3]. Wyniki analiz przeprowadzonych w ostatniej dekadzie wskazują na znaczący odsetek chorych z brakiem właściwego rozpoznania. Przykładem może być badanie przeprowadzone w poradni podstawowej opieki w Sierpcu (miasto z 20000 mieszkańców w województwie mazowieckim). Jego wynik wykazał, że w tej jednostce rozpoznanie POChP było ustalone tylko u około 18\% chorych [3]. Jeszcze gorsze wyniki uzyskano w badaniu wykonanym na Śląsku. W praktyce jednego z lekarzy rodzinnych podstawowej opieki zdrowotnej Górniczego Zespołu Lecznictwa Ambulatoryjnego obejmującej 1026 chorych właściwe rozpoznanie POChP było ustalone tylko u 1\% chorych [4]. Tymczasem badaniem spirometrycznym potwierdzono występowanie POChP u 6,04\%, a u chorych powyżej 40. rż. - u $8,1 \%[4]$.

POChP jest powszechną chorobą, niestety w poradniach podstawowej opieki zdrowotnej często pozostaje nierozpoznana

\section{Jak rozpoznać POChP?}

Przewlekłą obturacyjną chorobę płuc należy podejrzewać u osób powyżej 40. rż., które palą papierosy (lub były narażone na inne czynniki ryzyka), u których występują objawy, takie jak zadyszka, duszność i kaszel (często z wykrztuszaniem plwociny).

Adres do korespondencji: prof. dr hab. n. med. Ewa Jassem, Klinika Alergologii GUMed, ul. Dębinki 7, 80-211 Gdańsk, e-mail: ejassem@gumed.edu.pl DOI: 10.5603/PiAP.2014.0039

Copyright (C) 2014 PTChP

ISSN 0867-7077 


\section{Tabela 1. Nasilenie obturacji oskrzeli (wg GOLD i PTChP)}

\begin{tabular}{lc}
\hline Nasilenie obturacji oskrzeli & FEV $_{\mathbf{1}}$ \\
\hline I stopień & $>80 \%$ \\
II stopień & $80-50 \%$ \\
III stopień & $50-30 \%$ \\
IV stopień & $<30 \%$ \\
\hline
\end{tabular}

Objaśnienia skrótów w tekście

Podstawą rozpoznania POChP jest stwierdzenie nieodwracalnej obturacji oskrzeli za pomocą badania spirometrycznego po podaniu krótkodziałającego środka rozkurczowego. Rozpoznanie potwierdza wartość wskaźnika $\mathrm{FEV}_{1} / \mathrm{FVC}$ (forced vital capacity) $<70 \%$, natomiast wskaźnik $\mathrm{FEV}_{1}$ wskazuje na stopnień obturacji (tab. 1).

Badanie spirometryczne jest niezbędne do rozpoznania POChP. Przy przygotowaniu sprzętu do badania (kalibracji) oraz podczas samego wykonywania spirometrii należy kierować się zaleceniami European Respiratory Society/ /American Thoracic Society (ERS/ATS) i Polskiego Towarzystwa Chorób Płuc (PTChP) [5, 6]. Powinno się wykonać co najmniej trzy pomiary, przy czym wartości wskaźników $\mathrm{FEV}_{1}$ i FVC nie powinny się różnić o więcej niż $150 \mathrm{ml}$. Do oceny przyjmuje się najwyższe uzyskane wyniki. Ważne jest odpowiednie przygotowanie chorego do badania. Należy pamiętać o odstawieniu leków, które mogą wpływać na wyniki badania spirometryczego - między innymi krótkodziałające leki rozszerzające oskrzela należy odstawić około 8 godzin przed badaniem oraz długodziałające leki rozszerzające oskrzela - około 24 godziny przed badaniem. Na około 2 godziny przed badaniem chory nie powinien przyjmować obfitego posiłku, palić papierosów lub podejmować wysiłku fizycznego. Wskazane jest unikanie picia kawy i mocnej herbaty w tym czasie.

Próba rozkurczowa polega na podaniu choremu krótkodziałającego leku rozkurczającego oskrzela w inhalacji (w Polsce zaleca się salbutamol w dawce $400 \mu \mathrm{g}$, rzadziej bromek ipratropium w dawce $160 \mu \mathrm{g}$ ) i wykonaniu badania spirometrycznego po około 10-15 minutach od podania salbutamolu albo po około $30 \mathrm{minu}-$ tach w przypadku podania bromku ipratropium. W przypadku POChP wskaźnik $\mathrm{FEV}_{1} /$ FVC utrzymuje się po podaniu leku poniżej 0,7 (70\%). Przyrost $\mathrm{FEV}_{1}$ przekraczający $200 \mathrm{ml}$ (12\%) może natomiast świadczyć o nadreaktywności oskrzeli. Taka sytuacja może wystąpić w przypadku współwystępowania astmy (zespół nakładania POChP/ /astma) lub w czasie zaostrzenia POChP.
Badanie spirometryczne wykonane po podaniu środka rozszerzającego oskrzela pozwala na potwierdzenie rozpoznania POChP, gdy $\mathrm{FEV}_{1} /$ $/$ FVC $<$ DGN

Potwierdzenie rozpoznania za pomocą spirometrii stanowi podstawę refundacji leków. Wiele niepublicznych zakładów opieki zdrowotnej posiada spirometry, zatem rozpoznanie może być ustalone na miejscu. W przypadku niemożności wykonania badania spirometrycznego we własnym ośrodku wykaz poradni chorób płuc i poradni alergologicznych, które dysponują spirometrami, można znaleźć na internetowych stronach poszczególnych oddziałów NFZ.

Od kilku lat w Polsce działa program wczesnego wykrywania chorób odtytoniowych (w tym POChP) adresowany do osób powyżej 18. rż. palących papierosy. Program ten w zakresie diagnostyki POChP dotyczy kobiet i mężczyzn pomiędzy 40. a 65. rż., którzy nie mieli wykonanych badań spirometrycznych $w$ ramach programu profilaktyki POChP w ciągu ostatnich 36 miesięcy, u których nie zdiagnozowano wcześniej, w sposób potwierdzony badaniem spirometrycznym, POChP, przewlekłego zapalenia oskrzeli lub rozedmy. Bezpłatne badania w ramach programu można wykonać w zakładach opieki zdrowotnej, które podpisały z NFZ umowę na realizację programu. Do takiej jednostki można zgłosić się osobiście lub umówić na wizytę telefonicznie, przy czym nie jest potrzebne skierowanie [7]. Wydaje się, że informację o programie warto umieszczać we wszystkich poradniach rodzinnych w widocznym miejscu.

\section{Jak wstępnie ocenić zaawansowanie POChP?}

Zaawansowanie POChP określa się za pomocą wskaźników zaproponowanych przez międzynarodową grupę ekspertów w 2011 roku [8]. Wskaźniki te umożliwiają ustalenie kategorii (grupy) zaawansowania (ryc. 1). Należą do nich: 1) stopień obturacji,

2) objawy POChP,

3) liczba zaostrzeń POChP w ostatnim roku.

Dodatkowym elementem oceny są choroby współistniejące.

Stopnień obturacji (tab. 1) jest ważnym czynnikiem szeroko pojętego ryzyka w POChP. Nasilona obturacja $\left(\mathrm{FEV}_{1}\right.$ poniżej $50 \%$ należnej wartości) wiąże się z reguły z cięższym przebiegiem choroby i częstymi zaostrzeniami, w tym wymagającymi leczenia szpitalnego $[9,10]$. Zaleca się wykonywanie badania spirometrycznego co 


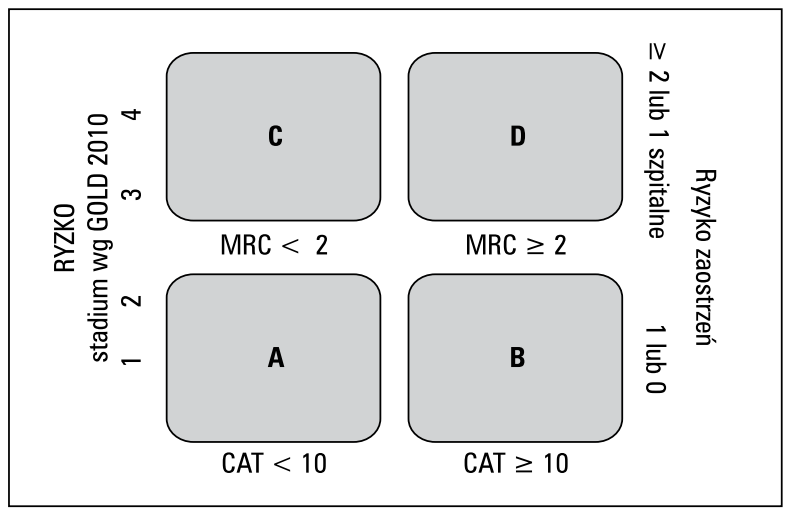

Rycina 1. Grupy (kategorie) zaawansowania POChP; objaśnienia skrótów w tekście

\section{Tabela 2. Skala nasilenia duszności MRC (wg PTChP)}

\begin{tabular}{cl}
\hline Stopień & Uwarunkowania wystąpienia duszności \\
\hline 0 & Duszność występuje tylko podczas dużego wysiłku \\
1 & $\begin{array}{l}\text { Zadyszka występuje podczas szybkiego marszu po } \\
\text { płaskim terenie lub podczas wchodzenia na niewielkie } \\
\text { wzniesienie }\end{array}$ \\
2 & $\begin{array}{l}\text { Duszność występuje podczas chodzenia po płaskim } \\
\text { terenie w tempie osoby zdrowej w tym samym wieku } \\
\text { lub występuje konieczność zatrymania się }\end{array}$ \\
& $\begin{array}{l}\text { dla złapania oddechu podczas chodzenia po płaskim } \\
\text { terenie we własnym tempie }\end{array}$ \\
& $\begin{array}{l}\text { Występuje konieczność zatrzymania się dla złapania } \\
\text { oddechu po przejściu około 100 metrów lub po } \\
\text { kilkunastominutowym spacerze po płaskim terenie }\end{array}$ \\
& $\begin{array}{l}\text { Duszność występuje po opuszczeniu domu lub po } \\
\text { rozebraniu się }\end{array}$ \\
\hline Objaśnienia skrótów w tekście
\end{tabular}

najmniej raz w roku w celu identyfikacji chorych, u których dochodzi do szybkiego obniżenia $\mathrm{FEV}_{1}$, gdyż są to chorzy o szczególnie dużym ryzyku pogorszenia choroby, wymagający konsultacji specjalisty [8].

Do najczęstszych objawów POChP zalicza się duszność i obniżenie tolerancji wysiłku. Oceny nasilenia objawów można dokonać za pomocą skali duszności MRC (Medical Research Council) (tab. 2) lub za pomocą testu wpływu POChP na życie chorego - CAT (COPD assessment test). Test CAT znajduje się na licznych stronach internetowych, między innymi na stronie Polskiego Towarzystwa Chorób Płuc [11] lub na www. www.pochp.eu, stronie adresowanej do chorych na zaawansowaną POChP i ich rodzin. Test CAT pozwala ocenić nie tylko nasilenie duszności, ale także nasilenie kaszlu, odkrztuszania i inne objawy wpływające na codziennie życie oraz ogra-

\section{Tabela 3. Najczęstsze choroby współwystępujące z POChP}

Choroby sercowo-naczyniowe, w tym zastoinowa niewydolność

krążenia, migotanie przedsionków

Nowotwory, w tym rak płuca, krtani, przełyku, żołądka

Endokrynologiczne, w tym cukrzyca, osteoporoza

Psychiczne, w tym lęk i depresja

Pokarmowe, w tym choroba wrzodowa

Krwiopochodne, w tym niedokrwistość

Infekcyjne, w tym stała kolonizacja oskrzeli folą chorobotwórczą, np. H. influenzae

Płucne, w tym włóknienie płuc

niczenie aktywności chorego w wyniku POChP, a to z kolei pozwala na pośrednią ocenę jakości życia [12]. W Polsce praktycznie nie stosuje się trzeciego zalecanego testu - CCQ (clinical COPD questionnaire) [8].

Chorzy o znaczących objawach to ci, którzy mają drugi (lub wyższy) stopnień nasilenia duszności mierzonej w skali MRC (to oznacza chorych, którzy co najmniej odczuwają zadyszkę idąc po płaskim terenie w tempie zdrowej osoby w swoim wieku) lub wynik CAT jest równy lub większy niż 10 punktów. Zgodność obu testów $\mathrm{w}$ jest duża [13]. Jednak w przypadku uzyskania niejednoznacznych wyników (np. wynik testu MRC wskazuje na kategorię A, a wynik CAT na kategorię B) za podstawę oceny przyjmuje się „gorszy” wynik.

Trzecim elementem decydującym stopniu zaawansowania POChP jest liczba zaostrzeń w ostatnim roku obserwacji. Za grupę o wysokim ryzyku pogorszenia POChP (kategoria C i D) uznaje się chorych, którzy mieli co najmniej dwa zaostrzenia wymagające podania antybiotyku lub doustnych (systemowych) steroidów lub co najmniej jedno zaostrzenie leczone w szpitalu. Hospitalizacja z powodu zaostrzenia jest istotnym niekorzystnym czynnikiem rokowniczym w odniesieniu do przeżycia [14].

Ważną częścią wstępnej oceny jest także ustalenie, na jakie inne schorzenia uskarża się chory. Wielu chorych po 60. rż. ma dwie lub więcej chorób współistniejących (tab. 3). Do najczęstszych należą choroby sercowo-naczyniowe. Duża liczba chorych, dotyczy to zwłaszcza zaawansowanej POChP, ma depresję i nasilony lęk. Te czynniki mogą w istotny sposób ograniczać aktywność fizyczną i intelektualną i przyczyniać się do pogorszenia przebiegu choroby. Wczesne rozpoznanie i właściwe leczenie depresji i lęku mają zatem 
istotne znaczenie [15]. Należy zwrócić uwagę na częste współwystępowanie POChP z rakiem płuca (około 30\%) - obturacja oskrzeli i rozedma są, poza paleniem papierosów, istotnymi czynnikami ryzyka dla tego nowotworu [16-18].

Chorzy z obturacją ciężkiego i bardzo ciężkiego stopnia $\left(\mathrm{FEV}_{1} \leq 50 \%\right)$, z objawami utrzymującymi się pomimo standardowego leczenia oraz z częstymi zaostrzeniami wymagają konsultacji pneumonologa co najmniej raz w roku w celu weryfikacji leczenia oraz wczesnej identyfikacji przewlekłej niewydolności oddychania.

U każdego chorego diagnozowanego w kierunku POChP należy wykonać RTG klatki piersiowej w dwóch projekcjach (PA i boczne) w celu wykluczenia raka płuca (z uwagi na wspólny czynnik ryzyka, jakim jest palenie tytoniu).

\section{Jakie parametry należy monitorować u chorych na POChP?}

Przy każdej wizycie należy upewnić się, czy chory nie pali tytoniu. U chorych uzależnionych od tytoniu lub takich, którzy powrócili do nałogu, należy leczyć zespół uzależnienia lub skierować chorego do poradni przeciwtytoniowej lub pneumonologicznej.

Przy każdej wizycie należy zwracać uwagę na objawy POChP. Do monitorowania przebiegu choroby przydatny jest test CAT, test składający się z 8 pytań. Odpowiedzi są oceniane w skali od 0 do 5 . Najwyższa liczba punktów odpowiada najbardziej nasilonym objawom. Zmianę wyników o dwa punkty uznaje się za istotną klinicznie.

Przynajmniej raz do roku należy wykonać badanie spirometryczne w celu rozpoznania chorych z szybko pogarszającą się czynnością płuc.

U chorych ze stałą dusznością utrzymującą się pomimo leczenia i z objawami tak zwanego serca płucnego należy ocenić saturację krwi i w przypadku zmniejszenia wartości poniżej 92\% wykonać badanie gazometryczne krwi w celu wczesnego rozpoznania niewydolności oddychania.

Należy monitorować występowanie zaostrzeń na przestrzeni roku. Uwzględnia się zaostrzenia wymagające podania antybiotyku, stosowania systemowych glikokortykosteroidów i leczenia szpitalnego.
Co najmniej raz w roku należy określić masę ciała chorego. Wskaźnik BMI (body mass index) jest jednym z istotnych czynników wpływających na rokowanie. U chorych, u których BMI jest mniejsze niż 21, należy rozważyć podawanie wysokobiałkowych preparatów i konsultację u dietetyka. Nagły ubytek masy ciała (więcej niż 10\% w czasie 6 miesięcy) może wskazywać na proces rozrostowy w obrębie klatki piersiowej.

W przypadku zmiany charakteru kaszlu, nawracających zapaleń płuc (zwłaszcza w tym samym obszarze), krwioplucia należy wykonać badania obrazowe klatki piersiowej. Przy zlecaniu klasycznej radiofotografii konieczne jest uwzględnienie dwóch projekcji — zdjęcia PA i bocznego. W przypadku podejrzenia procesu rozrostowego alternatywę dla klasycznej radiofotografii może stanowić niskodawkowa tomografia komputerowa.

Wskazana jest ocena zdolności do podejmowania wysiłku. Uznane narzędzie do takich pomiarów stanowi test 6 -minutowego chodu. Test ten nadaje się także do oceny skuteczności rehabilitacji. Należy zachęcać chorych do aktywności fizycznej oraz rehabilitacji ogólnie usprawniającej i oddechowej.

Należy monitorować przebieg POChP. Podział na kategorie pozwala wyróżnić chorych o małym ryzyku - grupy A i B i dużym - grupy C i D. Z kolei grupy A i C są związane z mniejszym niekorzystnym wpływem objawów POChP na stan zdrowia chorego. W grupach C i D nasilenie objawów jest znaczące i z reguły wpływa to w istotny sposób na jakość życia chorych (tab. 4). Wyniki badań prowadzonych w ramach projektu Evaluation Of COPD Longitudinally To Identify Predictive Surrogate End-Points (ECLIPSE) pokazują, że w grupach o mniejszym ryzyku i zaawansowaniu obturacji (grupy A i B) u około 30\% dochodzi do pogorszenia stopnia zaawansowania w trakcie trzyletniej obserwacji [19]. Najpewniej wczesne rozpoznanie i właściwe leczenie mogłoby zmniejszyć ten niekorzystny odsetek. Lekarze POZ powinni dokładać starań, żeby jak najwcześniej rozpoznać POChP. Wprawdzie podkreśla się, że naturalna historia POChP nie jest dokładnie znana [20], na podstawie analiz dużych badań, takich jak TOwards a Revolution in COPD Health (TORCH) i Understanding Potential Long-term Impacts on Function with Tiotropium 10 (UPLIFT), można jednak przypuszczać, że im wcześniej włącza się leczenie, tym efekt jest lepszy. 
Tabela 4. Ryzyko i objawy w poszczególnych kategoriach POChP, wg GOLD 2014

\begin{tabular}{|c|c|c|c|c|c|}
\hline Kategoria & Opis & FEV $_{1}$ & $\begin{array}{l}\text { Zaostrzenia } \\
\text { w ciągu roku }\end{array}$ & CAT & mMRC \\
\hline A & $\begin{array}{c}\text { małe ryzyko } \\
\text { mało objawów }\end{array}$ & $>50 \%$ & $<1$ & $<10$ & $0-1$ \\
\hline B & $\begin{array}{c}\text { małe ryzyko } \\
\text { dużo objawów }\end{array}$ & $>50 \%$ & $<1$ & $\geq 10$ & $\geq 2$ \\
\hline C & $\begin{array}{c}\text { duże ryzyko } \\
\text { mało objawów }\end{array}$ & $\leq 50 \%$ & $\geq 2$ & $<10$ & $0-1$ \\
\hline$D$ & $\begin{array}{c}\text { duże ryzyko } \\
\text { dużo objawów }\end{array}$ & $\leq 50 \%$ & $\geq 2$ & $\geq 10$ & $\geq 2$ \\
\hline
\end{tabular}

Tabela 5. Korzyści z zerwania z nałogiem palenia papierosów u chorych na POChP [22-25]

Zahamowanie spadku FEV

Zmniejszenie objawów

Poprawa jakości życia

Zmniejszenie ryzyka zaostrzeń

Poprawa rokowania

Objaśnienia skrótów w tekście

\section{Jak leczyć chorego na POChP?}

\section{Leczenie zespołu uzależnienia od tytoniu}

Palenie tytoniu jest najistotniejszym czynnikiem ryzyka wystąpienia POChP i niekorzystnym czynnikiem rokowniczym [20]. Korzyści płynące $\mathrm{z}$ zerwania $\mathrm{z}$ nałogiem są nie do przecenienia u chorych na POChP (tab. 5). Lekarz rodzinny obowiązany jest do umieszczenia wywiadu dotyczącego palenia tytoniu w karcie chorego oraz do przeprowadzenia tak zwanej minimalnej interwencji u chorych nadal palących [26]. W przypadku utrzymywania się nałogu należy skierować chorego do poradni przeciwtytoniowej lub poradni pneumonologicznej w celu dalszego leczenia.

Zespół uzależnienia od tytoniu jest chorobą (ICD-10 - F.17) - wymaga rozpoznania i leczenia, tak jak inne przewlekłe choroby

\section{Farmakoterapia w POChP}

Właściwe leczenie farmakologiczne pozwala na opanowanie objawów choroby, poprawia tolerancję wysiłku oraz — w efekcie, poprawia jakość życia. Jednocześnie umożliwia zmniejszenie ryzyka zaostrzeń i zgonu [27-30], a w grupach mniej zaawansowanych i młodszych chorych hamuje postęp choroby [31, 32].
Wczesne rozpoznanie i leczenie może poprawić przebieg POChP

\section{Leki rozszerzajace oskrzela \\ Leki krótkodziałające}

W grupie chorych bez objawów, z $\mathrm{FEV}_{1}>$ 50\% należnej wartości (kategoria/grupa A) dopuszcza się w ramach pierwszego wyboru przyjmowanie wyłącznie krótkodziałających leków rozszerzających oskrzela w inhalatorkach. U chorych bardziej zaawansowanych (kategorie B-D) leki te stosuje się jedynie doraźnie, podstawą terapii są leki długodziałające. Krótkodziałające leki rozszerzające oskrzela w nebulizacji stosuje się w przypadku zaostrzenia POChP.

\section{Leki długodziałajace}

Wyróżnia się dwie grupy długodziałających leków stosowanych w inhalacjach wpływające na receptory muskarynowe oraz na receptory beta(2)-adrenergiczne w oskrzelach.

\section{Leki przeciwcholinergiczne}

Spośród długodziałających leków hamujących receptory muskarynowe (głównie receptory M3) najlepiej poznane jest tiotropium, dostępne na polskim rynku od ponad 10 lat. Wynik badania o akronimie POET udowodnił wysoką skuteczność tego preparatu w zapobieganiu zaostrzeniom i hospitalizacjom w przebiegu POChP. Tiotropium wydłuża czas do pierwszego zaostrzenia i do pierwszego ciężkiego zaostrzenia oraz zmniejsza liczbę zaostrzeń (w tym ciężkich) skuteczniej niż salmeterol (długodziałający lek beta(2)-adrenergiczny) [29]. Tiotropium poprawia także

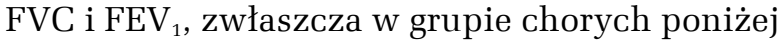
50. rż., u których spowalnia typowy dla POChP spadek FEV ${ }_{1}$ [30-32]. Tiotropium wpływa także korzystnie na zmniejszenie duszności i poprawę jakości życia [28]. Refundacja tiotropium 
zależy od stopnia nasilenia obturacji oskrzeli. Odpłatność 30\% przysługuje każdemu choremu na POChP potwierdzoną spirometrycznie. W sytuacji, kiedy wskaźnik $\mathrm{FEV}_{1}$ jest mniejszy niż $50 \%$ należnej wartości, refundacja jest pełna. Ostatnio pojawiły są dwa nowe leki — aklidyna i glikopyronium, które jednak nie są dotychczas refundowane.

\section{Długodziałajace leki pobudzajace receptory beta(2)-adrenergiczne}

Do leków tej grupy zalicza się salmeterol i formoterol. Zmniejszają duszność i rozdęcie płuc, poprawiają zdolność do wysiłku i jakość życia. Redukują także ryzyko zaostrzeń. Wszystkie preparaty długodziałających beta(2)-mimetyków, LABA (long-acting beta(2)-agonists) są w pełni refundowane przez NFZ u chorych z potwierdzonym rozpoznaniem POChP. U chorych na zaawansowane postaci POChP (kategoria/grupa C i D), u których wskazane jest zastosowanie wziewnych glikokortykosteroidów, zaleca się stosowanie leczenia skojarzonego (dwa leki w jednym inhalatorze). W ubiegłym roku wprowadzono na rynek nowy ultradługodziałający lek z tej grupy - indakaterol. Charakteryzuje się on szybkim czasem działania - skuteczność odczuwalna jest po kilku minutach od podania, co można porównać z krótkodziałającymi lekami z tej grupy. Jednocześnie efekt ten utrzymuje się przez 24 godziny, co umożliwia stosowanie leku w jednej dobowej dawce [33]. Jest skuteczniejszy niż tradycyjne leki z tej grupy w odniesieniu do poprawy czynności płuc i jakości życia chorych [34, 35]. Zmniejsza rozdęcie płuc i znacząco poprawia zdolność do wysiłku, przy jednoczesnej skuteczności w redukcji zaostrzeń [36].

\section{Leki przeciwzapalne}

Wziewne glikokortykosteroidy (wGS) są lekiem z wyboru u chorych, u których dochodzi do częstych zaostrzeń. Wyniki wielu badań potwierdziły znacząco korzystniejsze efekty w przypadku stosowania leków z grupy beta(2)-mimetyków i wGS w postaci preparatów skojarzonych niż w przypadku stosowania obu leków rozłącznie, w osobnych inhalatorach $[37,38]$. Warto pamiętać, że stosowanie wGS u chorych na POChP wiąże się z ryzykiem wystąpienia zapalenia płuc [39], jakkolwiek nie znane są dotychczas jednoznaczne czynniki predykcyjne, które w codziennej praktyce mogłyby być brane pod uwage w identyfikacji zagrożonych chorych [40]. Pełna refundacja obejmuje leki z grupy wGKS u chorych z $\mathrm{FEV}_{1}$ poniżej $60 \%$ należnej wartości, u których dochodzi do częstych zaostrzeń (dwa lub więcej $\mathrm{w}$ czasie roku lub jedno zaostrzenie wymagające leczenia szpitalnego).

Dostępne są ponadto inhibitory fosfodwuesterazy: inhibitor fosfodwuesterazy drugiej teofilina i czwartej — roflumilast. Leki te stosuje się jako drugi wybór (roflumilast) lub leczenie uzupełniające. Teofilina, w odróżnieniu od roflumilastu, jest w pełni refundowana, z uwagi na niekorzystny profil bezpieczeństwa stosuje się ją jako uzupełnienie leczenia. W krajach, w których leki w inhalacjach nie są dostępne, teofilina może być pierwszym wyborem.

Doustne (systemowe) steroidy stosuje się w przypadku zaostrzenia POChP. Skracają czas trwania zaostrzenia i czas hospitalizacji, zmniejszają liczbę niepowodzeń leczenia, znacząco poprawiają duszność i wartości gazometryczne [41]. Z uwagi na częste występowanie niepożądanych działań uważa się, że nie należy stosować systemowych steroidów u chorych w stabilnym okresie choroby.

\section{Leki ułatwiajqce wykrztuszanie}

Nie ma jednoznacznych rekomendacji dotyczących przewlekłego stosowania leków rozrzedzających wydzielinę oskrzelową. Wydaje się, że takie leczenie można rozważyć u chorych z częstymi zaostrzeniami, którzy nie mogą przyjmować wziewnych glikokortykosteroidów [42].

\section{Zasady leczenia farmakologicznego w POChP}

Leczenie farmakologiczne stosuje się w zależności od zaawansowania POChP (tab. 6). Zarówno rekomendacje PTChP jak i Global Initiative For Chronic Obstructive Lung Disease (GOLD) zalecają stosowanie leków wziewnych rozszerzających oskrzela o przedłużonym działaniu w przypadku kategorii od B do D. W wielu badaniach udowodniono, że stosowanie leków o przedłużonym działaniu jest w tych grupach korzystniejsze niż leki krótkodziałające. Nie ma natomiast dowodów na korzyści wynikające z długotrwałego stosowania doustnych glikokortykosteroidów.

Leczenie w POChP ustala się na podstawie klasyfikacji zaawansowania. Terapia wziewna jest pierwszym wyborem w każdej grupie.

Chorzy w grupie A - w Unii Europejskiej szacuje się ich liczbę na około 17 milionów mają wprawdzie obturację dróg oddechowych, ma ona jednak łagodny lub umiarkowany charakter. Chorzy z reguły nie odczuwają stałych objawów i najczęściej skarżą się na nietolerancję wysiłku. $\mathrm{W}$ tej sytuacji w pierwszym rzędzie wskazane jest przyjmowanie doraźnie krótkodziałających 
Tabela 6. Rozpoczynanie farmakologicznego leczenia w zależności od zaawansowania POChP (GOLD 2014)

\begin{tabular}{lccc}
\hline Kategoria & Pierwszy wybór & Drugi wybór & Inne możliwości* $^{*}$ \\
\hline A & SAMA lub SABA & LAMA lub LABA lub SAMA + SABA & Th \\
B & LAMA lub LABA & LAMA i LABA & SABA i/lub SAMA \\
& & & Th \\
C & wGS + LABA lub LAMA & LAMA i LABA & SABA i/lub SAMA \\
& & TAMA i iFD4 & karbocysteina \\
& LABA i iFD4 & SABA i/lub SAMA \\
D & Th
\end{tabular}

SABA — short acting beta(2)-agonists; SAMA — short acting antimuscarinic antagonists, LABA — long acting beta(2)-agonists; LAMA - long acting antimuscarinic antagonists; Th - teofilina; iFD4 — inhibitor fosfodwuesterazy-4; * Preparaty przedstawione w tej kolumnie mogą uzupełniać leczenie pierwszego lub drugiego wyboru, lub - w uzasadnionych przypadkach — mogą być stosowane samodzielnie; Preparaty w poszczególnych kolumnach wymieniane są zgodnie z kolejnością zastosowana w GOLD 2014 (z kolei w dokumencie GOLD są wymieniane zgodnie z kolejnością alfabetyczną)

leków rozszerzających oskrzela. Jeśli prowadzi to do częstego stosowania leków, można rozważyć włączenie leków długodziałających, jakkolwiek dowody na korzyść ze stosowania długodziałających preparatów w tej grupie są ograniczone, bowiem badania kliniczne $\mathrm{z}$ reguły obejmują chorych o większym stopniu zaawansowania.

Grupa B obejmuje chorych, u których wprawdzie obturacja nie jest bardzo nasilona i ryzyko zaostrzeń nieduże, jednak objawy POChP są częste i mają niekorzystny wpływ na życie chorego. W tej grupie lekami pierwszego wyboru są długodziałające leki rozszerzające oskrzela. Wybór preparatu zależy od dostępności, tolerancji i preferencji chorego. Jeśli pomimo regularnego leczenia objawy, zwłaszcza duszność, utrzymują się, można rozszerzyć leczenie o długodziałający lek rozszerzający oskrzela z drugiej grupy. W sytuacjach szczególnych, gdy leki te nie są dostępne lub stosowanie ich nie jest możliwe z powodu złej tolerancji (np. nietolerancja leków wziewnych może to dotyczyć pojedynczych chorych) można stosować leczenie uzupełniające (tab. 6).

Grupa C obejmuje chorych, którzy wprawdzie mają niewielkie objawy POChP, ale mają znaczną obturację oskrzeli $\left(\mathrm{FEV}_{1} \leq 50 \%\right.$ należnej wartości) i znaczne ryzyko zaostrzeń. Pierwszym wyborem w tej grupie są długodziałające leki z grupy antycholinergików lub preparaty złożone zawierające $\mathrm{w}$ jednym inhalatorze wziewne glikokortykosteroidy i beta(2)-mimetyki. W przypadku złej tolerancji preparatów złożonych możliwe jest łączne zastosowanie LAMA (long-acting muscarinic antagonist) i LABA lub połączenie któregoś z tych preparatów z inhibitorami fosfodwuesterazy-4. Jedynym zarejestrowanym, jakkolwiek nierefundowanym, preparatem $\mathrm{w}$ tej ostatniej grupie jest roflumilast. Leczenie z zastosowaniem roflumilastu zaleca się przede wszystkim u chorych, u których w klinicznym obrazie przeważa zapalenie oskrzeli.

W najbardziej zaawansowanej grupie D znajdują się chorzy, którzy z reguły mają schyłkową postać POChP - nasiloną obturację, stałe nasilone objawy i częste zaostrzenia, w tym zaostrzenia wymagające szpitalnego leczenia. U części chorych wystarcza zastosowanie preparatów złożonych (wziewne glikokortykosteroidy i beta(2)-mimetyki). W leczeniu pierwszego rzutu wskazane jest także łączenie złożonych preparatów z długodziałającymi lekami przeciwcholinergicznymi. W drugim rzucie można rozważyć połączenie leku złożonego lub LAMA z inhibitorem fosfodwuesterazy. U części chorych, u których nie dochodzi do częstych zaostrzeń, a wziewne glikokortykosteroidy są źle tolerowane, można zastosować LAMA i LABA.

\section{Rehabilitacja ogólnie usprawniająca i tak zwana oddechowa}

Rehabilitacja ogólnie usprawniająca powinna obejmować: fizjoterapię, poradę psychologiczną i poradę dietetyczną. Ważnym efektem rehabilitacji poza poprawą tolerancji wysiłku, zmniejszeniem ryzyka zaostrzeń jest znacząca poprawa jakości życia chorych w każdej grupie zaawansowania POChP. Tak zwana oddechowa fizjoterapia z reguły dotyczy nauki wykonywania toalety drzewa oskrzelowego (także z użyciem przyrządów, takich jak na przykład RC cornet ${ }^{\circledR}$, flutter $\left.{ }^{\circledR}\right)$ i poprawy efektywności oddychania (wydech przez „zasznurowane” usta, użycie „tłoczni brzusznej”). Szczególnie u chorych, u których dochodzi to tak zwanej paniki oddechowej, nauka kontroli oddechu 
powinna być połączona z poradą psychologiczną obejmującą techniki relaksacji.

W 2013 roku zwiększyła się dostępność do stacjonarnych i ambulatoryjnych kursów rehabilitacji dla chorych na przewlekłe choroby układu oddechowego prowadzonych zgodnie z rekomendacjami ATS/ERS [43]. Wydaje się, że w przypadku braku dostępności do zorganizowanych kursów rehabilitacji, chorzy na POChP mogą odnieść korzyść z mniej intensywnej fizjoterapii prowadzonej w warunkach domowych [44]. Warto pamiętać, że korzystne jest zastosowanie krótkodziałającego środka rozszerzającego oskrzela przed rozpoczęciem ćwiczeń. Ponadto, ćwiczenia muszą być dostosowane do możliwości chorego, bowiem niepożądanym efektem fizjoterapii prowadzonej w domu może być nagłe obniżenie ciśnienia parcjalnego tlenu we krwi.

Zalecenia PTChP rekomendują zastosowanie rehabilitacji u każdego chorego z rozpoznaniem POChP

\section{Domowe leczenie tlenem}

Przewlekła niewydolność oddychania, która jest następstwem progresji POChP, wymaga leczenia tlenem. Udowodniono, że długotrwałe (ponad 15 godzin dziennie) stosowanie tlenu, na przykład z koncentratora, poprawia wydolność chorych i rokowanie, zmniejsza ryzyko ciężkich zaostrzeń, i w efekcie poprawia jakość życia chorych. Wskazaniem do domowego leczenia tlenem (DLT) jest hipoksemia utrzymująca się w stabilnym okresie choroby $-\mathrm{PaO}_{2} \leq 55 \mathrm{~mm}$ Hg. Chorzy, którzy spełniają kryteria NFZ, otrzymują koncentrator tlenu $w$ ramach refundacji. Wykaz placówek prowadzących kwalifikację do DLT znajduje się na internetowych stronach NFZ.

\section{Zabiegi chirurgiczne}

Niektórzy chorzy na podstawie indywidualnie określonych wskazań mogą się kwalifikować do leczenia chirurgicznego. Obejmuje ono usunięcie dużych bulli rozedmowych, operacyjne zmniejszenie objętości płuc czy przeszczepienie płuc. Zwłaszcza ta ostatnia forma leczenia chirurgicznego wymaga wielodyscyplinarnych konsultacji.

\section{Szczepienia ochronne}

Zaleca się szczepienia przeciw grypie u wszystkich chorych na POChP, szczególnie po 60. rż. $\mathrm{W}$ przypadku braku szczepienia, chory powinien otrzymać od lekarza informację o korzyściach wy- nikających z zastosowania szczepionki przeciwgrypowej, a informacja o tym powinna się znaleźć w dokumentacji chorego. Trzeba zachęcać chorych do wykonania szczepienia przeciw pneumokokom.

\section{Zaostrzenie POChP}

Zaostrzenie definiuje się jako nasilenie objawów utrzymujące się dłużej niż 24 godziny i wymagające modyfikacji leczenia. $\mathrm{W}$ wielu badaniach klinicznych zaostrzenia dzieli się na takie, które wymagają: 1) podania leku przeciwbakteryjnego, 2) doustnych steroidów lub 3) leczenia szpitalnego. Przyczyną zaostrzeń są najczęściej zakażenia wirusowe i bakteryjne. Ważną rolę odgrywa także nieprawidłowe stosowanie inhalatorów (lub zaniechanie leczenia). Istotnym czynnikiem ryzyka zaostrzeń jest depresja, która utrudnia radzenie sobie z chorobą, powoduje brak aktywności fizycznej i intelektualnej, nasilając izolację chorego. Podkreśla się, że liczba zaostrzeń wzrasta wraz z zaawansowaniem choroby, można jednak wyodrębnić grupę chorych, u których dochodzi do częstych zaostrzeń niezależnie od nasilenia zmian (frequent exacerbators) [45].

Zaostrzenia powodują wiele niekorzystnych następstw - nasilają objawy, pogarszają czynność płuc i zmiany te utrzymują się u części chorych bardzo długo [46]. Zaostrzenia pogarszają ponadto jakość życia chorych i rokowanie [14]. Dotyczy to zwłaszcza zaostrzeń wymagających leczenia szpitalnego. Zarówno pobyt na oddziale jak i około miesięczny okres po wypisaniu ze szpitala, to czas kiedy ryzyko zgonu jest szczególnie istotne.

Właściwie postępowanie z uwzględnieniem wziewnych leków przeciwzapalnych może w istotny sposób ograniczyć ryzyko zaostrzeń - jest to jeden z głównych celów leczenia w POChP [8].

\section{Czy lekarz pierwszego kontaktu ma prawo rozpoznać i leczyć POChP?}

Wykonywanie zawodu lekarza polega na udzielaniu przez osobę posiadającą wymagane kwalifikacje, świadczeń zdrowotnych, w szczególności:

- badaniu stanu zdrowia,

- rozpoznaniu chorób i zapobieganiu im,

- leczeniu i rehabilitacji,

— udzielaniu porad,

— wydawaniu opinii i orzeczeń lekarskich.

Tak więc, zgodnie z obowiązującym w Polsce prawem dotyczącym wykonywania zawodu lekarza, każdy lekarz posiadający to prawo może rozpoznać POChP i je leczyć 
oraz kontynuować leczenie farmakologiczne pacjenta zastosowane $\mathrm{w}$ poradni specjalistycznej, zgodnie ze współczesną wiedzą medyczną, a jeżeli pacjent ma dolegliwości wymagające natychmiastowej pomocy, to ma nie tylko prawo, ale wręcz obowiązek leczenia chorego. Istotnym elementem przy rozpoznaniu POChP jest konieczność udokumentowania tej choroby badaniem spirometrycznym po podaniu odpowiedniej dawki leku rozkurczowego, na przykład $400 \mathrm{mcg}$ salbutamolu. Ponieważ w leczeniu POChP poziom refundacji niektórych leków jest uzależniony od wartości $\mathrm{FEV}_{1}$ w stosunku do wartości należnej, należy zwracać uwagę, czy $\mathrm{FEV}_{1}$ jest poniżej czy powyżej 50\% wartości należnej. Zgodnie z Rozporządzeniem Ministra Zdrowia z dnia 6 maja 2008 r. w sprawie ogólnych warunków umów o udzielanie świadczeń opieki zdrowotnej (\$12 ust. 6), lekarz podstawowej opieki zdrowotnej może kontynuować leczenie specjalistyczne, jeżeli posiada informację od lekarza specjalisty o rozpoznaniu, sposobie leczenia, rokowaniu, ordynowanych lekach, okresie ich stosowania i dawkowania oraz wyznaczonych wizytach kontrolnych. Informacja taka powinna być wydana w momencie ustalenia przez lekarza specjalistę diagnozy i podjęcia leczenia. Jeżeli chory przebywa pod stałą opieką specjalisty, lekarz pierwszego kontaktu powinien otrzymywać taką informację nie rzadziej niż raz w roku, a bezwzględnie w każdym przypadku zmiany leczenia przez specjalistę. Bardzo ważny jest jednak drugi aspekt tej sprawy, często nieznany lekarzom. Otóż obowiązek wydawania raz na 12 miesięcy pisemnej informacji do lekarza kierującego i lekarza podstawowej opieki zdrowotnej dotyczy pacjentów objętych opieką specjalistyczną leczonych długotrwale. Nie powinien być stosowany w przypadkach, gdy lekarz specjalista w pisemnej informacji do lekarza pierwszego kontaktu:

1) określi schemat leczenia,

2) wskaże konieczność wykonania przez podstawową opiekę zdrowotną dalszej określonej diagnostyki kontrolnej,

3) określi częstotliwość diagnostyki kontrolnej,

4) nie ustali na piśmie terminów dalszych wizyt specjalistycznych

Całkowitą opiekę nad chorym na POChP sprawuje wówczas lekarz pierwszego kontaktu. Kolejna wizyta u specjalisty wynikać powinna w tej sytuacji z aktualnego stanu zdrowia pacjenta i konieczności modyfikacji leczenia. Taka sytuacja w przypadku POChP wystąpi, kiedy chory będzie miał na przykład zaostrzenie choroby, a zwiększenie dawek leków lub zmiana leczenia nie przyniesie choremu poprawy (dynamika procesu chorobowego nasili się). Wtedy kolejna wizyta u specjalisty może być realizowana tylko na podstawie informacji od lekarza pierwszego kontaktu (nie ma potrzeby ponownego kierowania chorego do tego samego specjalisty, gdyż skierowanie może wydłużyć czas oczekiwania pacjenta na wizytę ze względu na błędne zapisanie pacjenta przez rejestrację poradni jako pierwszorazowego). Taki chory nie jest pacjentem pierwszorazowym i nie musi ponownie czekać w kolejce, nawet jeżeli do specjalisty nie chodził regularnie. $\mathrm{Na}$ informacji do specjalisty zawsze powinno się postawić dopisek PILNE. Należy przy tym pamiętać, że przypadek pilny to sytuacja, w której nie zachodzi konieczność natychmiastowego udzielenia pomocy pacjentowi, niemniej jednak, ze względu na stan zdrowia, odpowiednia pomoc medyczna winna być mu udzielona jak najszybciej, kiedy będzie to tylko możliwe, w tym przed innymi osobami już oczekującymi w kolejce na to samo świadczenie zdrowotne.

Częstym problemem jest kwestia powtórzenia recept u osób przewlekle chorych. Lekarz pierwszego kontaktu może wystawić receptę na trzy po sobie następujące okresy nieprzekraczające łącznie 90 dni przy określeniu dnia, od którego może nastąpić realizacja recepty. Lekarz pierwszego kontaktu może zatem wystawiać receptę na więcej niż jedno opakowanie leku. Pragnę podkreślić, że obowiązujące przepisy nie wykluczają możliwości wystawienia recept lekarskich w przypadku chorób przewlekłych przez lekarza podstawowej opieki zdrowotnej bez osobistego kontaktu z pacjentem. Ordynacja leków bez zbadania pacjenta, $w$ tym powtarzanie recept na dotychczas stosowane leki, w praktyce zawsze powinna zależeć od oceny konkretnej sytuacji dokonanej przez lekarza. Odpowiedzialność za skutki zdrowotne związane z powtórzeniem dotychczas ordynowanych leków zawsze ponosi lekarz. Powyższa sytuacja powinna znaleźć odzwierciedlenie w dokumentacji medycznej chorego, na nazwisko którego wystawiono receptę na leki. W mediach pojawiają się często nie do końca prawdziwe informacje o zakazie wypisywania recept bez obecności pacjenta. W dniu 31 lipca 2013 roku Narodowy Fundusz Zdrowia wyjaśnił jednak, że nie będzie kwestionował udzielania i sprawozdawania porad oznaczonych kodami ICD-10: Z76.0 - Powtórzenie recepty lub Z71.0 - Osoby konsultujace się w imieniu innej osoby. Lekarz pierwszego kontaktu ma zatem prawo taką receptę wystawić przewlekle choremu na prośbę pacjenta lub rodziny. (Komunikat NFZ 
z dnia 19.08.2013 r.) Zupełnie odwrotnie wygląda sytuacja w przypadku leczenia przez specjalistę. W opinii NFZ, w ramach leczenia specjalistycznego nie ma możliwości wypisania recepty bez zrealizowania porady. W obecnej wersji systemu rozliczeniowego ambulatoryjnej opieki specjalistycznej nie istnieje pojęcie porady recepturowej.

Podsumowując, lekarz pierwszego kontaktu może leczyć chorego z POChP, może przepisywać mu leki refundowane, ma nawet o wiele szersze i bardziej elastyczne możliwości leczenia niż lekarz specjalista, musi tylko z tych możliwości w sposób świadomy korzystać, mając zawsze na względzie przede wszystkim dobro chorego.

Przepisy nie ograniczają kompetencji zawodowych i autonomii decyzji lekarzy podstawowej opieki zdrowotnej, w tym także w odniesieniu do diagnozowania i leczenia chorób przewlekłych.

\section{Podstawa prawna:}

1. Rozporządzenie Ministra Zdrowia z 6 maja 2008 r. w sprawie ogólnych warunków umów o udzielanie świadczeń opieki zdrowotnej (Dz. U. z 2008 r. Nr 81, poz. 484).

2. Ustawa z 5 grudnia 1995 r. o zawodach lekarza i lekarza dentysty (t.j. z 2011 r. nr 277, poz. 1634 ze zmianami)

\section{Piśmiennictwo:}

1. Górecka D., Jassem E., Pierzchała W., Śliwiński P. Zalecenia Polskiego Towarzystwa Chorób Płuc dotyczące rozpoznawania i leczenia przewlekłej obturacyjnej choroby płuc (POChP). Pneumonol. Alergol. Pol. 2012, 80, 220-254

2. Gibson G.J., Loddenkemper R., Lundback B., Sibille Y. Respiratory health and disease in Europe: the new European Lung White Book. Eur. Respir. J. 2013; 42: 559-563.

3. Bednarek M., Maciejewski J., Woźniak M. i wsp. Prevalence, severity and underdiagnosis of COPD in the primary care setting. Thorax 2008; 63: 402-440.

4. Siatkowska H., Kozielski J., Ziora D. Chorzy na przewlekłą obturacyjną chorobę płuc w praktyce lekarza podstawowej opieki zdrowotnej. Pneumonol. Alergol. Pol. 2010; 78: 112-120.

5. Miller M.R., Hankinson J., Brusasco V. i wsp. ERS/ATS Task Force report on standardisation of lung function testing. Standarisation of spirometry. Eur. Respir. J. 2005; 26: 319-338.

6. Zalecenia Polskiego Towarzystwa Chorób Płuc dotyczące wykonywania badań spirometrycznych. Pneumonol. Alergol. Pol. 2006; 74: 5-44.

7. http://www.nfz.gov.pl/new/?katnr $=6 \& d$ zialnr $=145 \&$ art $\mathrm{nr}=4662(\mathrm{z}$ dnia 4 stycznia 2014).

8. http://www.goldcopd.org/uploads/users/files/GOLD_Report2014_Jan30.pdf.

9. Kesten S., Celli B., Decramer M. i wsp. Adverse health consequences in COPD patients with rapid decline in $\mathrm{FEV}_{1}$ - evidence from UPLIFT trial. Respir. Med. 2011; 12: 129.

10. Beeh K.M., Glaab T., Stowasser S. i wsp. Characterisation of exacerbation risk and exacerbator phenotypes in the POET-COPD trial. Respir. Med. 2013; 14: 116-136.

11. http://akademiaptchp.pl/strefa_specjalisty/zalecenia_polskiego_towarzystwa_chorob_pluc/aneks_2._test_oceny_ przewleklej_obturacyjnej_choroby_pluc_cat_copd_assessment_test.

12. Agusti A., Soler J.J., Molina J. i wsp. Is the CAT questionnaire sensitive to changes in health status in patients with severe COPD exacerbations? Copd 2012; 9: 492-498.

13. Jones P.W., Adamek L., Nadeau E., Banik N. Comparisons of health status scores with MRC grades in COPD: implications for the GOLD 2011 classification. Eur. Respir. J. 2013; 42: 647-654.
14. Suissa S., Dell'Aniello S., Ernst P. Long-term natural history of chronic obstructive pulmonary disease: severe exacerbations and mortality. Thorax 2012; 67: 957-963.

15. Antoniu S.A. Predictors of depression in chronic obstructive pulmonary disease patients. Expert Rev. Respir. Med. 2011; 5: 333-335.

16. Jassem J.M., Bobowicz M., Słomiński J.M. The incidence of chronic obstructive pulmonary disease in advanced non-small cell lung cancer patients. Adv. Palliat. Med. 2007; 6: 99-102.

17. Kishi K., Gurney J.W., Schroeder D.R. i wsp. The correlation of emphysema and airway obstruction with the risk of lung cancer: a matched-controlled study. Eur. Respir. J. 2002; 19: 1093-1098.

18. Smith B.M., Schwartzman K., Kovacina B. i wsp. Lung cancer histologies associated with emphysema on computed tomography. Lung Cancer 2012; 76: 61-66.

19. Agusti A., Edwards L.D., Celli B. i wsp. Characteristics, stability and outcomes of the 2011 GOLD COPD groups in the ECLIPSE cohort. Eur. Respir. J. 2013; 42: 636-647.

20. Kohansal R., Soriano J.B., Agusti A. Investigating the natural history of lung function. Chest 2009; 135: 1330-1341.

21. Doll R., Peto R. Mortality in relation to smoking: 20 years' observations on male British doctors. BMJ 1976; 2: 1525-1536.

22. Anthonisen N.R., Connett J.E., Kiley J.P. i wsp. Effects of smoking intervention and the use of an inhaled anticholinergic bronchodilator on the rate of decline of $\mathrm{FEV}_{1}$. The Lung Health Study. JAMA 1994; 272: 1497-1505.

23. Kanner R.E., Connett J.E., Williams D.E., Buist A.S. Effects of randomized assignment to a smoking cessation intervention and changes in smoking habits on respiratory symptoms in smokers with early chronic obstructive pulmonary disease: the Lung Health Study. Am. J. Med. 1999; 106: 410-416.

24. Anthonisen N.R., Skeans M.A., Wise R.A. i wsp. The effects of a smoking cessation intervention on 14.5-year mortality: a randomized clinical trial. Ann. Intern. Med. 2005; 142: 233-239.

25. Willemse B.W., ten Hacken N.H., Rutgers B. i wsp. Effect of 1-year smoking cessation on airway inflammation and asymptomatic smokers. Eur. Respir. J. 2005; 26: 835-845.

26. Kozielski J., Górecka D., Grzelewska-Rzymowska I. i wsp. Rozpoznanie i leczenie choroby tytoniowej. Zalecenia Polskiego Towarzystwa Chorób Ftyzjopneumonologicznego. Pneumonol. Alergol. Pol. 2005; 73: 5-39.

27. Calverley P.M., Anderson J.A., Celli B. i wsp. Salmetrol and fluticasone propionate and survival in chronic obstructive pulmonary disease. N. Engl. J. Med. 2007; 356: 775-789.

28. Nannini L.J., Poole P., Milan S.J. i wsp. Combined corticosteroid and long-acting beta2-agonist versus placebo for chronic obstructive pulmonary disease. Cochrane Database Syst. Rev 2013, CD003794.

29. Tashkin D.P., Celli B., Senn S. i wsp. A 4-year trial of tiotropium in chronic obstructive pulmonary disease. N. Engl. J. Med. 2008; 359: 1543-1554.

30. Vogelmeier C., Hederer B., Glaab T. i wsp. Tiotropium versus salmeterol for the prevention of exacerbations of COPD. N. Engl. J. Med. 2011; 364: 1093-1103.

31. Jenkins C.R, Jones P.W., Calverley P.M. i wsp. Efficacy of salmeterol/fluticasone propionate by GOLD stage of chronic obstructive pulmonary disease: analysis form randomized, placebo-controlled TORCH study. Respir. Res. 2009; 10: 1-9.

32. Morice A.H., Celli B., Kesten S. i wsp. COPD in young patients: a pre-specified analysis of the four-year trial of tiotropium (UPLIFT). Respir. Med. 2010; 104: 1659-1667.

33. Rennard S., Bnatje T., Centanni S. i wsp. A dose-ranging study of indacaterol in obstructive airways disease, with tiotropium comparison. Respir. Med. 2008; 102: 1033-1044.

34. Kornmann O., Dahl R., Centanni S. i wsp. Indacaterol efficacy evaluation using $150 \mu \mathrm{g}$ doses with COPD. Eur. Respir. J. 2010; 37: 273-279.

35. Dahl R., Chung K.F., Buhl R. i wsp. Efficacy of e new once-daily LABA, indacaterol versus twice-daily LABA formoterol in COPD. Thorax 2010; 65: 473-479.

36. Steiropoulos P., Archontogeorgis K., Nena E., Bouros D. New developments in the management of COPD: clinical utility of indacaterol $75 \mu \mathrm{g}$. Int. J. COPD 2014; 9: 1-7. 
37. Szafranski W., Cukier A., Ramirez A. i wsp. Efficacy and safety of budesonide/formoterol in the management of chronic obstructive pulmonary disease. Eur. Respir. J. 2003; 21 : 74-81.

38. Nannini L.J., Poole P., Milan S.J., Kesterton A. Combined corticosteroid and long-acting beta(2)-agonist in one inhaler versus inhaled corticosteroids alone for chronic obstructive pulmonary disease. Cochrane Database Syst. Rev. 2013, CD006826.

39. Suissa S., Patenaude V., Lapi F., Ernst P. Inhaled corticosteroids in COPD and the risk of serious pneumonia. Thorax 2013; 68: 1029-1036.

40. Calverley P.M., Stockley R.A., Seemungal T.A. i wsp. Reported pneumonia in patients with COPD: findings from INSPIRE study. Chest 2011; 139: 505-512.

41. Walters J.A., Gibson P.G., Wood-Baker R. i wsp. Systemic corticosteroids for acute exacerbation of chronic obstructive pulmonary disease. Cochrane Database Syst. Rev. 2009; CD001288.
42. Tse H.N., Raiteri L., Wong K.Y. i wsp. High-dose N-acetylocysteine in stable COPD: the 1-year, double-blind, randomized, placebo-controlled HIACE study. Chest 2013; 144: 106-118.

43. Spuit M.A., Singh S.J., Carvey Ch. i wsp. An official American Thoracic Society/European Respiratory Society statement: key concepts and advances in pulmonary rehabilitation. Am. J. Respir. Crit. Care Med. 2013; 188: e13-63.

44. Corhay J.L., Nguyen D., Duysinx B. i wsp. Should we exclude elderly patients with chronic obstructive pulmonary disease from a long-time ambulatory pulmonary rehabilitation programme? J. Rehabil. Med. 2012; 44: 466-472.

45. Hurst J.R., Vestbo J., Anzueto A. i wsp. Susceptibility to exacerbation in chronic obstructive pulmonary disease. NEJM 2010; 363: 1128-1138.

46. Seemungal T.A., Donaldson G.C., Bhowmik A. i wsp. Time course and recovery of exacerbation in patients with chronic obstructive pulmonary disease. Am. J. Crit. Care Respir. Med. 2000; 161: 1608-1613. 